\title{
The Effect of the Locus of Control, Financial Knowledge and Income on Investment Decisions
}

\section{Rosyeni Rasyid ${ }^{1}$, Muthia Roza Linda ${ }^{2}$, Dina Patrisia ${ }^{3}$, Halkadri Fitra ${ }^{4}$, Yuliza Susanti ${ }^{5}$}

${ }^{1}$ Dept. of Management, Faculty of Economics, Universitas Negeri Padang, Padang, Indonesia

$\square$ (e-mail) rosyenirasyid@yahoo.com

2Dept. of Management, Faculty of Economics, Universitas Negeri Padang, Padang Indonesia

$\triangle$ (e-mail) muthia_rozalinda@yahoo.com

3Dept. of Management, Faculty of Economics, Universitas Negeri Padang, Padang Indonesia

$\triangle$ (e-mail) patrisiadina@yahoo.com

${ }^{4}$ Dept. of Management, Faculty of Economics, Universitas Negeri Padang, Padang Indonesia

$\square$ (e-mail) halkadri.feunp@gmail.com

${ }^{5}$ Faculty of Economics, Universitas Negeri Padang, Padang Indonesia

$\square$ (e-mail) yulizasusanti11@gmail.com

\begin{abstract}
The objectives of this study are to analyze: 1) the effect of locus of control on investment decisions; 2) the effect of financial knowledge on investment decisions; 3 ) the effect of income on investment decisions. The population of this research is all employees of PT. Pertamina (Persero) of Padang branch, which amounted to 68 people, with a total sample of 43 people. The sample is the employee who conducts investment activities. Data were obtained through the distribution of questionnaires. It was then it analyzed with multiple linear regression analysis using SPSS Software version 24.0. The results indicate that: 1) locus of control has a significant effect on investment decision; 2) financial knowledge has a significant effect on investment decision, and 3) income has a significant effect on investment decision. The locus of control, financial knowledge, and income affect $57.5 \%$ of employee's investment decisions; the remaining $42.5 \%$ is affected by other factors. Out of the three variables studied, financial knowledge is the most dominant variable in affecting investment decisions.
\end{abstract}

Keywords: Investment Decision, Locus of Control, Financial Knowledge, Income

\section{Introduction}

In today's globalization era, unexpected needs for consumerism, such as the fulfillment of the need for self-actualization in technology, the need for house ownership or vehicle ownership, and the need for entertainment, often rise along with the requirement for a larger funding source. These unpredictable needs motivate people to collect funds to fulfill those needs. To fulfill these needs, they have to work for their present and future life. Several options are available as ways to fulfill those need, one of which is by saving or investing funds.

According to Tandelilin (2010), investment is a commitment to invest a certain amount of funds or other resources that one has at the moment with the goal of gaining some benefits in the future. Every individual needs to invest because the objective of an investment is to make some money, or in the broadest sense, to improve the welfare. There are several specific reasons on why a person invests: to earn wealth in the future, to remedy the bad effects of inflation, and to save tax expenditures (Tandelilin, 2010). However, investing is not an easy task; one should be literate enough to avoid losses or being trapped in a bad investment, or even being the victim of a tricky fraudster. Therefore, to be an investor, one should have knowledge about the types of investments that are available and the risks of each of them. One should not let himself to be tricked by a persuasive and smooth-talking fraudster who let his funds vanish even to its last cents. 
Investment decisions made by investors can be influenced by market behavior and the rational and irrational behavior of the investor himself. These rational and irrational behaviors have become a part of behavioral finance. Nofsinger (2001) defines the behavioral finance as a subject that studies on how humans actually behave in a financial setting. Nofsinger also mentions that behavioral finance studies the psychological factors that will affect financial decision making on the enterprise and the financial markets. It is concluded that behavioral finance is an approach that explains how a person makes an investment as affected by psychological factors.

Sindhu and Kumar (2014) argued that the investment decisions means that the investors made the decisions on where, how, and how much the funds will be invested towards various financial instruments, with the objectives of generating income or the value appreciation. Dewi and Iramani (2014) interpreted the investment decisions as a policy or decision that is taken to invest the capital in one or more assets, to gain future benefits. Investment decisions also mean issues on how someone should allocate funds into the forms of investment that are profitable in the future.

The fundamental thing in the investment decision process is to understand the relation between the expected return and the risk of an investment. The relation between risk and expected return on an investment is a linear and direct relationship. It means that the higher expected return, the higher the risk that must be considered

Manurung (2012) mentions several psychological factors that affect the decisions to invest and the results one wants to achieve. The analysis of the decision to invest that use psychological science and financial science is known as Behavioral Finance. Several factors that could affect the decision to invest are: First, the locus of control, which is an action where a person connects events that happen in his life with external forces beyond his control (Robbins, 2001). The basic concept of Locus of Control is derived from the social learning theory developed by Patten (2005), that the locus of control is related to a person's degree of confidence about events, fate, fortune, and destiny that is happening to him, whether it is due to internal factors or external factors. Locus of control is associated with a person's view or his perception of the conditions and his prediction about what will happen in the future over the decision he has made.

internal and external constructs. If a person believes that what is happening is always under his control and he always takes responsibility for every decision, he is included in the internal locus of control. Locus of control refers to the perceptions toward events both positive and negative as a consequence of actions or self-actions that are under his own control. On the contrary, a person who believes that events in his life are beyond his control is included in the external locus of control, which refers to the belief that an event has no direct relationship to the self-action and it is beyond his own control (Lefcourt, 1982).

Individuals are categorized into having an internal locus of control because he believes that all events that happen are under his own control. This means that the person has a great potential inside himself to determine his life direction, no matter whether environmental factors will support him or not. On the other hand, individuals who have an external locus of control is an individual who believes that all events that occur are beyond his control. This is similar to a study conducted by Adi and Mardiasmo (2002) that stated that locus of control affects the attitude of a person in handling the events that happened to him.

The second factor is the financial knowledge, a factor that also plays an important role in making the decision for the investment planning. The financial knowledge is the knowledge on how to manage and to plan the fund so that it could bring benefits and prevent loss. This theory is supported by the results of a study by Lusardi (2008) which suggest that a low financial knowledge affects future financial planning, while illiteracy over the basic concept of finance could be related with the low level of investment planning. Furthermore, the study of Pritazahara \& Sriwidodo (2015) stated that financial knowledge becomes inseparable to someone's life. The financial knowledge is a useful tool for making financial decisions; however, the financial knowledge rates are still relatively low in many 
countries.

Hilgert and Hogarth (2003) argued that financial knowledge is a conceptual definition of the financial literacy. The financial knowledge also has a close relationship with financial literacy or financial education. Financial knowledge could be facilitated and could be well-comprehended through financial education or financial literacy. Mason and Wilso (2000) stated that financial literacy is a decision-making of an individual that uses a combination of multiple skills, resources, and contextual knowledge, to manage information and to make decisions based on the financial risks. On the other hand, the financial knowledge is a person's mastery over various things about the financial world (Kholilla \& Iramani, 2013).

Ida and Dwinta (2010) reported that to possess a financial knowledge, a person needs to develop the financial skills and learn how to use the financial tools. Financials skill is a technique to make the decision in the management of personal finance. Setting up a budget, selecting an investment, pick an insurance plan, and using credit are examples of the financial skills. Financials tools are forms and charts be used in the decision making of personal financial management.

A study by Hastings and Mitchell (2010) stated that the financial knowledge is very important in managing one's personal finances, and to help him in deciding things for his financial welfare. The term financial management here is referred to the definition of investment, which is a commitment to invest a number of funds or other resources he committed at present, with the goal of gaining benefits in the future (Tandelilin, 2010).

The third factor that affects investment decisions is the income. According to a study by Kusumawati (2013), a person's income is a related concern in making the investment decision. It is also in line with the statement of Hilgert (2003) that respondents with lower incomes are less likely report their financial bills in comparison to the higher incomes. Thus, people who are financially below average are less likely to invest compared to those who earn more. This means that the income level of the people affects their interest to invest some part of their income.

According to the dictionary of investment, an income is the total gross of the annual income of an individual that comes from wages, business transactions and various investments. Investopedia also defines income as an "earning before tax" of a person and it is used in the calculation of adjusted gross income of an individual for income tax purposes. This study uses the definition of income as the amount of money earned by a person for the work he has done.

The Central Bureau of Statistics (2013) grouped income levels into four categories:

a. Very high category : more than IDR3,500,000

b. High category : IDR2,500,000-IDR3,500,000

c. Medium category : IDR1,500,000-IDR, 400.000

d. Low category : : less than IDR1,500,000

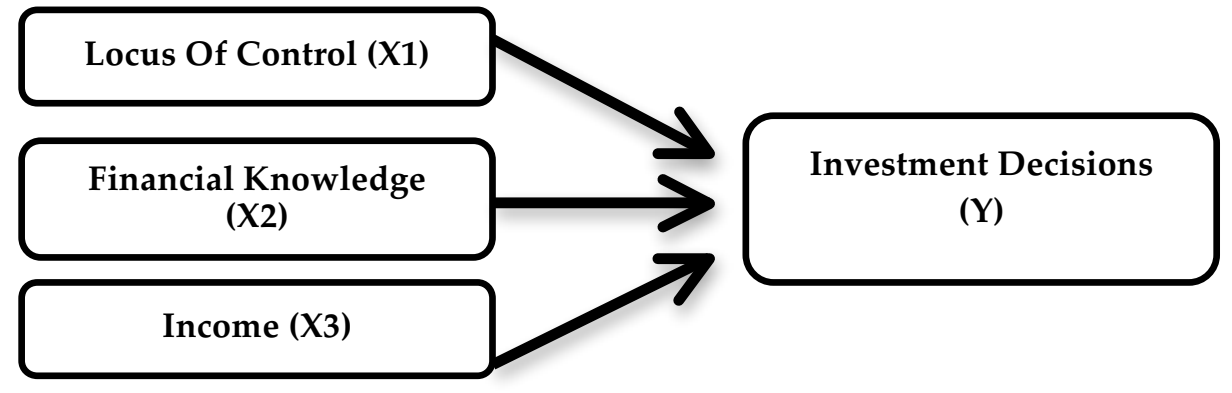

Figure 1 Conceptual framework

The study that supports the relation between income to investment decisions includes the research of Kusumawati (2013), which states that someone's income is related to his consideration of investment decisions.

Based on theories and previous studies described above, the hypotheses are formulated as follows: 
$\mathrm{H}_{1}$ Locus of control has a significant effect on investment decisions.

$\mathrm{H}_{2}$ Financial knowledge has a significant effect on investment decisions.

$\mathrm{H}_{3}$ Income has a significant effect on investment decisions.

\section{Methods}

This research is classified as descriptive research using field research method or the descriptive survey and explanatory research to explain the causal relationship between variables and to test the formulated hypotheses.

The population in this research is all permanent employees of PT Pertamina (Persero) of Padang branch, with the total of 68 people. The sampling technique is purposive sampling, which takes the samples as based on certain criterion. The criterion of the sample is the employee who made investment activities, with as many as 43 employees as the sample.

The data were obtained through the distribution of questionnaires. The questionnaire contains some structured questions related to investment decisions which filled by respondents. The data were then analyzed using multiple linear regression analysis with SPSS software ver. 24.0.

Table 1 The operational definitions

\begin{tabular}{|c|c|c|c|}
\hline No & Variable & Indicator & Source \\
\hline 1 & $\begin{array}{l}\text { Locus of } \\
\text { Control }\end{array}$ & $\begin{array}{ll}\text { 1. Internal locus of control } \\
\text { 2. } & \text { External locus of control } \\
\end{array}$ & Rotter (1996) \\
\hline 2 & $\begin{array}{l}\text { Financial } \\
\text { Knowledge }\end{array}$ & $\begin{array}{l}\text { 1. Basic finance knowledge } \\
\text { 2. Saving and borrowing } \\
\text { 3. Insurance } \\
\text { 4. Investment }\end{array}$ & $\begin{array}{l}\text { Chen and } \\
\text { Volpe (1998) }\end{array}$ \\
\hline 3 & Income & $\begin{array}{l}\text { Income could be adjusted in } \\
\text { regard to the total income of } \\
\text { wages and salaries }\end{array}$ & $\begin{array}{l}\text { Ida and } \\
\text { Dwinta } \\
(2010: 140)\end{array}$ \\
\hline 4 & $\begin{array}{l}\text { Investment } \\
\text { Decision }\end{array}$ & $\begin{array}{ll}\text { 1. } & \text { Return } \\
\text { 2. } & \text { Risk }\end{array}$ & $\begin{array}{l}\text { Tandelilin } \\
\text { (2010) }\end{array}$ \\
\hline
\end{tabular}

\section{Results and Discussion}

The data used in this research were data that fulfilled the requirements of validity test, reliability test, and normality test. Before the data were processed with multiple linear regression analysis, a descriptive analysis of the variable of locus of control was done. This was to classify the sample into either the internal group or external group. Based on the descriptive analysis, the highest value was the external locus of control, which means that most employees of PT Pertamina belong to the group of external locus of control.

The results of multiple linear regression analysis using SPSS software ver.24.0 are as follows.

Table 2 Multiple Regression Test Results

\begin{tabular}{llccc}
\hline \multirow{2}{*}{ Model } & \multicolumn{3}{c}{$\begin{array}{l}\text { Unstandardized } \\
\text { Coefficients }\end{array}$} & $\begin{array}{l}\text { Standardized } \\
\text { Coefficients }\end{array}$ \\
\cline { 3 - 5 } & \multicolumn{3}{c}{$\begin{array}{c}\text { Std. } \\
\text { Error }\end{array}$} & Beta \\
\hline 1 & (Constant) & -0.940 & 1.207 \\
\\
\cline { 2 - 4 } & Locus_of_Control & 0.445 & 0.129 & 0.361 \\
\hline & Financial_Knowledge & 0.581 & 0.279 & 0.281 \\
\hline Income & 0.179 & 0.064 & 0.388 \\
\hline
\end{tabular}

Source: Data of Calculation Result using SPSS, 2018 
Based on the results in Table 2 above, the multiple linear regression equation is formulated as follows:

$$
\mathrm{Y}=-0.940+0.445 \mathrm{LoC}+0.581 \mathrm{FK}+0.179 \mathrm{In}
$$

The above equation could be read as:

a. The constant value is 0.940 with a negative sign, which means that without the variable of locus of control (X1), financial knowledge (X2), and income $(X 3)$, there is no investment decision that will be made by the respondent.

b. The variable of locus of control has a regression coefficient value of 0.445 with a positive sign, which means that any increase in the variable of locus of control (X1), will result in an increase in the respondents' decision to invest.

c. The variable of financial knowledge (X2) has a regression coefficient value of 0.581 with a positive sign, which means that any increase in the variable of financial knowledge (X2), will result in an increase in the respondents' decision to invest.

d. The variable of income (X3) has a regression coefficient value of 0.179 with a positive sign, which means that any increase in the variable of income (X3), will result in an increase in the respondents' decision to invest.

\section{Coefficient of Determination $\left(R^{2}\right)$}

The coefficient of determination $\left(\mathrm{R}^{2}\right)$ shows the proportions between the independent variables and the dependent variable, the rest of coefficient is explained by other variables that are not included in the model, the error in formulation model and experimental error. In this study, the results of the coefficient of determination test $\left(\mathrm{R}^{2}\right)$ are shown in Table 3 below.

Table 3 Coefficient of determination $\left(\mathrm{R}^{2}\right)$

\begin{tabular}{llcll}
\hline Model & R & R Square & $\begin{array}{l}\text { Adjusted } \\
\text { R Square }\end{array}$ & $\begin{array}{l}\text { Std. Error } \\
\text { of the } \\
\text { Estimate }\end{array}$ \\
\hline 1 & $0.778^{a}$ & 0.605 & 0.575 & 0.22967 \\
\hline a. Predictors: (Constant), Income, Locus_of_Control, \\
Knowledge_management \\
Source: Data on Calculation Result using SPSS, 2018 \\
\end{tabular}

Table 3 shows that the adjusted value of $\mathrm{R}^{2}$ obtained is 0.575 . It means that $57.50 \%$ of the variable of investment decisions could be explained by the variables of locus of control, financial knowledge, and income. The remaining $42.50 \%$ is explained by other variables which are not included in this study.

Statistical F-Test test basically shows whether all of the independent variables included in the regression model have an effect on the dependent variable.

Table 4 Statistical F-test

\begin{tabular}{|c|c|c|c|c|c|c|}
\hline \multicolumn{2}{|c|}{ Model } & \multirow{2}{*}{$\begin{array}{l}\text { Sum of } \\
\text { Squares } \\
3.155\end{array}$} & \multirow{2}{*}{$\frac{\mathrm{df}}{3}$} & \multirow{2}{*}{$\begin{array}{l}\text { Mean } \\
\text { Square } \\
1.052\end{array}$} & \multirow{2}{*}{$\begin{array}{l}\mathrm{F} \\
19.937\end{array}$} & \multirow{2}{*}{$\begin{array}{l}\text { Sig. } \\
0.000^{b}\end{array}$} \\
\hline 1 & Regression & & & & & \\
\hline & Residual & 2.057 & 39 & 0.053 & & \\
\hline & Total & 5.212 & 42 & & & \\
\hline \multicolumn{7}{|c|}{ a. Dependent Variable: Inv_Decision } \\
\hline \multicolumn{7}{|c|}{ b. Predictors: (Constant), Income, Locus_of_Control, } \\
\hline
\end{tabular}

Table 4 indicates that the value of counted-F is 19.937 with a significance level of $0.000<0.05$. This means that there is a simultaneous significant effect between all independent variables on the 
dependent variable. Thus, it is also concluded that this model is worthy to be tested. Hypothesis Test (t-test)

Table 5 Partial Test Results

\begin{tabular}{lll}
\hline Model & Counted $\mathbf{t}$ & Sig. \\
\hline (Constanta) & -0.779 & 0.441 \\
\hline Locus of Control & 3.453 & 0.001 \\
\hline Financial Knowledge & 2.083 & 0.044 \\
\hline Income & 2.795 & 0.008 \\
\hline Source: Data on Calculation Result using SPSS, 2018 &
\end{tabular}

a. First Hypothesis

Based on the result, the significant value of locus of control is equal to $0,001<0,05$. It means that the first hypothesis that the locus of control has a significant effect on investment decisions can be accepted.

b. Second Hypothesis

Based on the result, the significant value of financial knowledge is equal to $0.044<0.050$. It means that the second hypothesis that the financial knowledge has a significant effect on investment decisions can be accepted.

c. Third Hypothesis

Based on the result, the significant value of income is equal to $0,008<0,05$. It means that the third hypothesis that the income has a significant effect on investment decisions can be accepted.

\section{The Effect of Locus of Control on Investment Decisions}

Based on the results of hypothesis testing, the locus of control has a significant effect on investment decisions. It can be seen that the locus of control has a regression coefficient of 0.445 with a positive effect or direction on the investment decision, and has a significance value of $0.001<0.05$. This indicates that employees of PT Pertamina of Padang branch believe that events happened to them are caused by factors beyond their control and they only accept for what has happened and believes that everything that is happening is a destined to be.

These results are in line with research by Perry and Morris (2005) which states that the locus of control affects the financial management. In their study, the financial management is referred to the decision to invest. The study of Adi and Mardiasmo (2002) also stated that locus of control affects one's attitude in dealing with events that are happening to him.

\section{The Effect of Financial Knowledge on Investment Decision}

Based on the results of this study, the hypothesis test found that the financial knowledge has a significant effect on investment decisions of the employee of PT Pertamina (Persero) of Padang branch. The results also show that financial knowledge has a regression coefficient that is equal to 0.581 with a positive effect or direction on the investment decision, with the significance value of $0.044<0.05$. This indicates that financial knowledge (such as knowledge in basic financial, insurance, savings and loans and investment) of the employees of PT Pertamina of Padang branch affects the employees in making investment decisions.

The results of this study are in line with the study results of Hastings and Mitchell (2010) which states that financial knowledge is very helpful to manage one's personal finances and to help him in deciding things about his financial welfare. The financial terms here is referred to the decision to invest. This result is also supported by Yulianti and Silvy (2013) who stated that financial knowledge and financial experience affect the behavior of the planning of family financial investment. Susnaningsih, Desrir and Hesty (2014) also said that the level of financial knowledge of a person has a strong effect on his decision in managing his personal finances as well as his company finances. 
Based on this study results, the coefficient of regression of financial knowledge is higher than the other variables, so it is concluded that financial knowledge is the main basic factor for a person to plan the investment activity. Respondents who have a low level of financial knowledge are more dominantly have no concept/plans to conduct investment activities. On the contrary, the respondents who have a high level of financial knowledge will prefer to invest. Based on the results of this study in PT Pertamina (Persero) of Padang branch, the financial knowledge of its employees is evenly distributed, as many employees understand the effect of a good financial responsibility in making an investment.

\section{The Effect of Income on Investment Decision}

Based on the study results, the hypothesis testing on the income variable found that income has a significant effect on investment decisions. The results also show that the income has a regression coefficient of 0.179 with a positive effect or direction toward investment decisions, with the significance value of $0.008<0.05$. This indicates that the income level of the employees of PT. Pertamina of Padang branch affects their investment decision-making. The decision to invest depends on the amount of their income, in which a greater income will result in a more diverse investment that they make.

This is in line with the study of Kusumawati (2013) that a person's income has an effect on his personal finance management, and that the higher their income the higher their consideration to make the investment decisions. It is also in line with the study of Jones et al, (2009) that there is a positive relationship between income and the responsible behavior of financial management. Thus, a higher income will make someone has more responsible financial behavior. The results of this study also supported the theory of the perspective of financial behavior in adaptive financial decision making, that the nature of the decisions and the environment affect the type of process used. A person with a better socio-demographic status will have a better type of process of decision-making in investment. The result is also in line with the study of Seetharaman, Wang and Zang (2014) that the income level has a strong effect on the object of investment.

\section{Conclusions}

Based on the results, it is concluded that:

1. Locus of control has a positive and significant effect on investment decisions with a significance value less than 0.05 , which is 0.001 .

2. Financial knowledge has a positive and significant effect on investment decisions with a significance value less than 0.05 , which is 0.044 .

3. Income has a positive and significant effect on the decision with a significance value less than 0.05 , which is 0.008 .

\section{Acknowledgments}

The authors would like to express their sincere gratitude to Faculty of Econonics Universitas Negeri Padang that has funded this research and all those involved in the completion of the research.

\section{References}

Adi N, Henrika C, Tri, Mardiasmo. (2002). Analisis pengaruh strategi institusi, budaya institusi, dan conflict of interest terhadap budgetary slack. Jurnal Ekonomi dan Bisnis Indonesia, 17(1).

Hastings, J \& Mitchell, O. S. (2010). How Financial Literacy and Impatience Shape Retirement Wealth and Investment Behaviors. Brown University and NBER.

Hoffmann, A., Eijie, J. \& Jager, W. (2006). Individual Investors' Needs and Conformity Behavior. Working Paper. 
Jones, C. P. et al. (2009). Invesment: Analysis and Management, Indonesian Adaption. Salemba Empat \& John Willey.

Kreitner R, \& Kinicki, A. (2001). Organizational Behavior. Fifth Edition. International Edition. New York: Mc Graw-Hill Companies Inc.

Kusumawati, Melisa. (2013). Faktor Demografi, Economic Factors dan Behavioral Motivation dalam Pertimbangan Keputusan Investasi di Surabaya.

Mason, C. L. J \& Wilson, R. M. S. (2000). Conceptualising Financial Literacy. Occasional Paper, 7. Loughborough: Business School, Loughborough University.

Muat, Susnaningsih, Miftah, Desrir, \& Wulandari, Hesty. (2014). Analisis tingkat literasi keuangan dan dampaknya terhadap keputusan pinjaman pribadi. Economics and Business Research Festival, 13 November 2014.

Patten, M.D. (2005). An analysis of the impact of locus of control on internal auditor job performance and satisfaction. Managerial Auditing Journal, 20(1).

Perry, Vanessa G. \& Marlene D. Morris. (2005). Who is control? The role of self perception, knowledge, and income in explaining consumer financial behaviour. Journal of Personal finance, $8(1)$.

Rasyid, Rosyeni. (2012). Analisis tingkat literasi keuangan mahasiswa program studi manajemen Fakultas Ekonomi Universitas Negeri Padang. Jurnal Kajian Manajemen Bisnis, 1(2).

Seetharaman, Ananth, Wang, Xu, \& Zhang, Sanjian. (2014). An empirical analysis or the effects of accounting in audit commitees on Non-GAAP earning exclusions. Accounting Horizons, 28(1).

Tendelilin, E. (2010). Portofolio dan Investasi. Kanisius.

Yulianti, N. \& Silvy, M. (2013). Sikap pengelola keuangan dan perilaku perencanaan investasi keluarga di Surabaya. Journal of Business and Banking, 3(1).

Zaini, A. (2010). Pengaruh biaya produksi dan penerimaan terhadap pendapatan petani padi sawah di Loa Gagak Kabupaten Kutai Kertanegara. Jurnal EPP, 7(1). 